\title{
Perancangan Aplikasi Sistem Manajemen Anggaran Perjalanan Dinas Luar Kota Berbasis Java Pada PT. AMBC
}

\author{
Bambang Kiswanto ${ }^{1}$, Muhamad Irsan ${ }^{2}$, dan Retno Nengsih ${ }^{3}$ \\ 1,2,3 Universitas Indraprasta PGRI \\ Jl. Raya Tengah No.80, RT.6/RW.1, Kel. Gedong, Kec. Pasar Rebo \\ Kota Jakarta Timur, Daerah Istimewa Jakarta 13760 \\ Alamat kampus Penulis ketiga, kota kode pos \\ bamabangpart@gmail.com \\ atstairway@gmail.com \\ retnonengsih3dharma@gmail.com
}

\begin{abstract}
Abstrak - Penelitian ini bertujuan untuk mengetahui apliksi manual yang sedang berjalan , membuat aplikasi manajemen anggaran perjalanan dinas luar kota, melakukan analisis dan pengujian aplikasi serta untuk melakukan implementasi anggaran perjalanan dinas luar kota. Metodologi penelitian yang digunakan dalam sistem pengolahan data yaitu teknik pengumpulan data seperti wawancara, observasi, studi dokumentasi, serta melakukan penelitian kepustakaan yang relevan dengan masalah sistem-sistem informasi. Metode pengembangan Aplikasi yang digunakan menggunakan metode grounded.
\end{abstract}

Kata kunci: Aplikasi, Manajemen, Anggaran Dinas

Abstrak - This study aims to find out the manual application that is currently running, create a budget management application for out-of-town business trips, analyze and test applications as well as to implement an out-of-town official travel budget. The research methodology used in the data processing system is data collection techniques such as interviews, observations, documentation studies, and conducting library research relevant to information systems problems. The application development method used uses the grounded method (grounded research).

Keyword: Application, Management, Office Budget

\section{Pendahuluan}

Biaya perjalanan dinas merupakan salah satu biaya yang harus dikeluarkan oleh suatu perusahaan bagi karyawannya yang ingin bekerja di luar kota[1]. Untuk saat ini biaya perjalanan dinas merupakan biaya yang cukup besar nilainya dan sering dianggarkan. Anggaran adalah suatu rencana yang disusun secara sistematis yang meliputi seluruh kegiatan perusahaan yang dinyatakan unit kesatuan moneter yang berlaku untuk jangka waktu periode tertentu yang akan datang[2]. Oleh karena itu, perlu adanya sistem informasi yang memudahkan karyawan dalam melaporkan kegiatan yang dilakukan, biaya yang dikeluarkan dan administrasi dalam mencetak anggaran perjalanan dinas untuk menghitung besarnya biaya yang di keluarkan saat melakukan perjalanan dinas. Selain itu, dengan menggunakan sistem informasi keamanan data akan lebih terjamin karena tersimpan dalam database dan mencegah penginputan ganda[3]. Pada saat ini perusahaan dalam pembuatan amggaran perjalanan dinas masih menggunakan sistem manual (excel), sehingga perhitungan biaya tidak dapat dilakukan secara real time dalam pembuatan laporan keuangan.

\section{Tinjauan Pustaka}

a. Perancangan

Perencananaan suatu sistem yang menyangkut berbagai rancangan sehingga akan menghasilkan sistem yang sesuai dengan hasil dari tahap analisa system yang kita buat[4].

b. Sistem

sistem yaitu komponen yang saling berhubungan dan saling berinteraksi satu sama lain untuk dimana sitem yang biasanya terbagi dalam sub sistem yang lebih kecil untuk mendukung sistem yang lebih besar [5].

c. Diagram Alir Data

Data Flow Diagram yang grafik menggambarkan aliran informasi dan transformasi yang diaplikasikan sebagai data yang mengatur dari masukan (Input) dan keluar (Ouput)[6].

d. Mysql

MySQL server basis data yang mampu menerima dan mengirimkan data dengan cepat menggunakan perintah-perintah SQL. 
e. Java

Java dapat dijalankan diberbagai computer [8]. Java berdiri disebuah mesin yang diberinama Java Virtual Machine (JVM).

f. Netbeans

Netbeans open source yang sering kali diasosiasikan dengan Java [9]. Akan tetapi IDE untuk membuat proyek-proyek Java saja, melainkan juga proyek seperti web service.

\section{Metode Penelitian}

Metode penelitian yang peneliti gunakan untuk mendapatkan informasi serta data-data yang diperlukan yaitu menggunakan metode deskriptif dengan tujuan untuk mendapatkan data secara detail, mendalam, dan juga aktual.

Maka peneliti melakukan metode pengumpulan data antara lain:

1. Metode observasi (Pengamatan langsung)

Peneliti dengancara pengamatan langsung kelapangan serta mengamati sistem yang sedang berjalan.

2. Metode interview (Wawancara)

Peneliti melakukan tanya jawab kepada kepala perpustakaan, yang berkaitan dengan masalah agar dapat di pecahkan sehingga memperoleh data-data yang benar-benar akurat.

3. Metode Studi Kepustakaan (Literature)

Metode pengummpulan data yaitu mempelajari literature baik berupa dokumen tertulis dan berupa gambar serta mengambil teori-teori yang berhubungan dengan judul penelitian ini.

\section{Hasil dan Pembahasan}

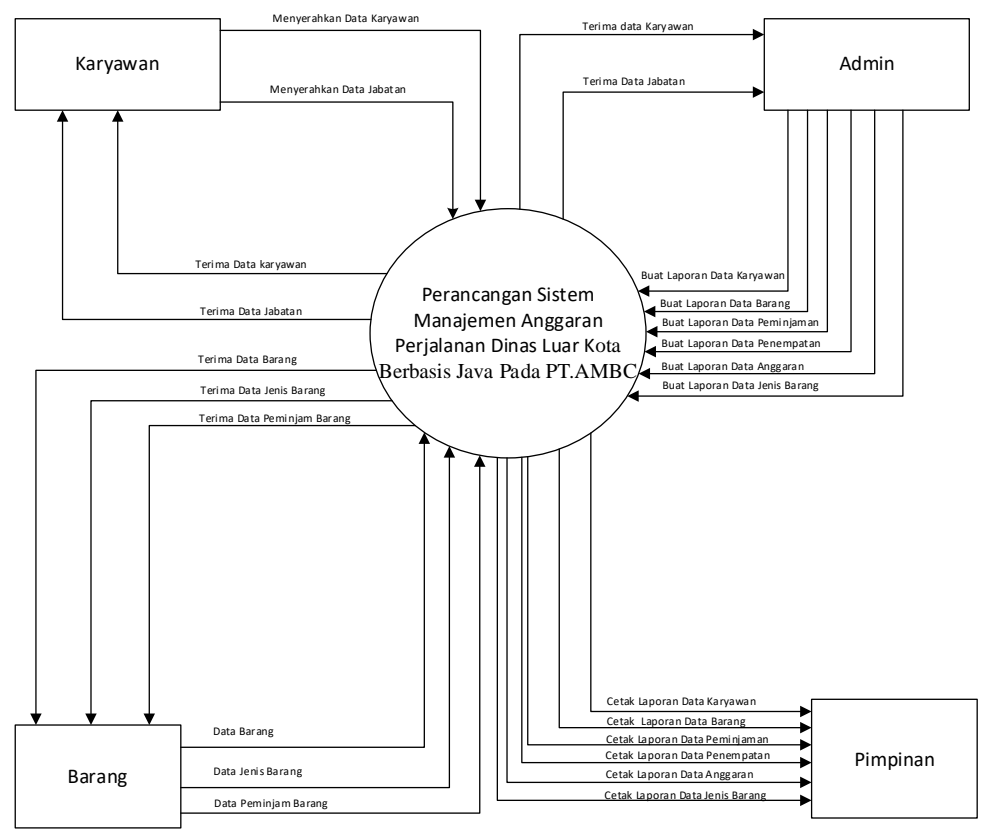

Gambar 1 Diagram Konteks Yang Diusulkan 


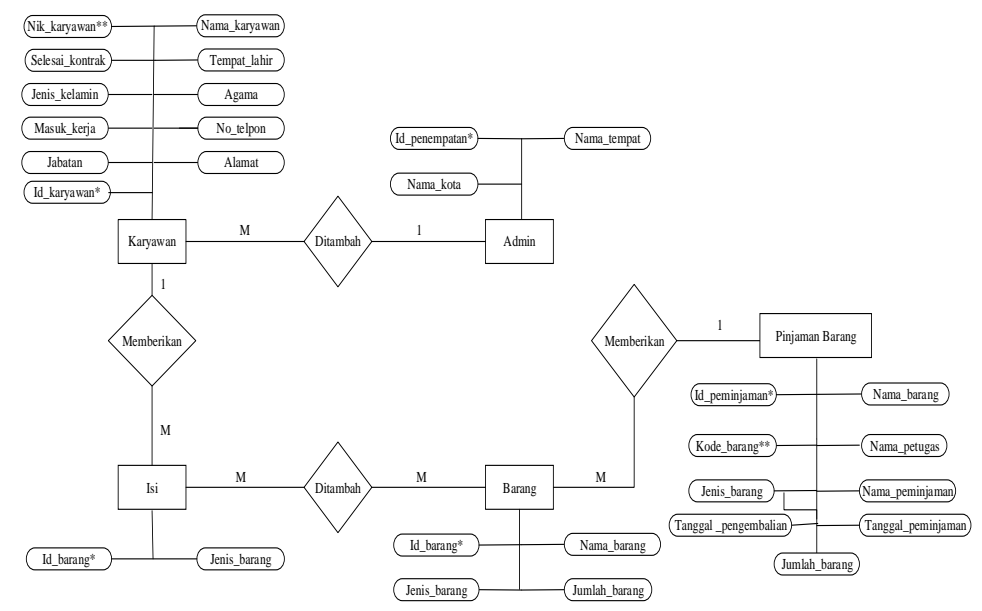

Gambar 2. Entity Relationship Diagram (ERD)
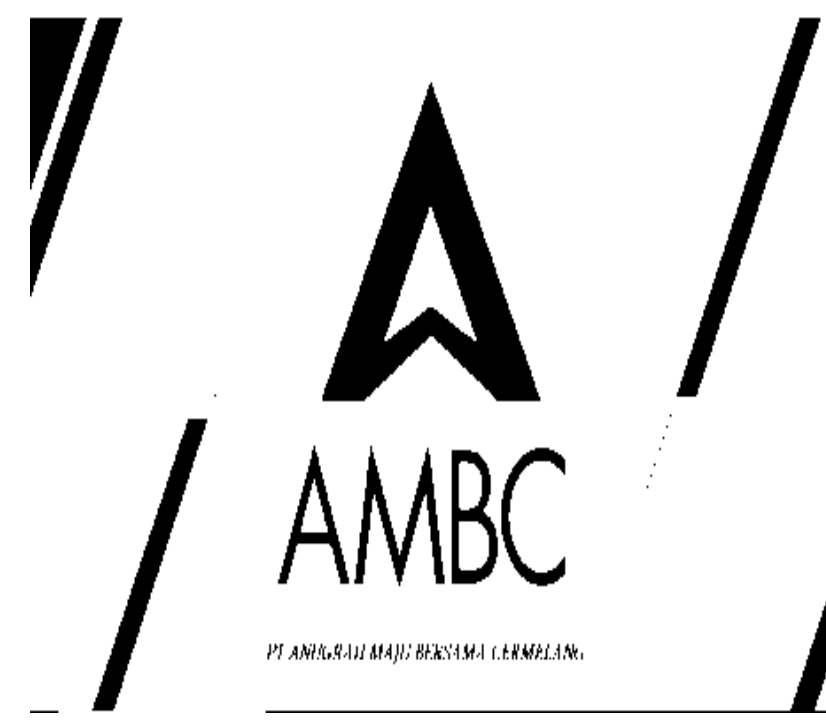

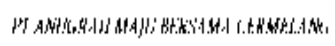

Gambar 3. Tampilan Layar Menu

Apabila pengguna dapat memasukkan nama pengguna dan kata sandi dengan tepat, maka menu utama akan tampil dan program siap untuk dijalankan. 


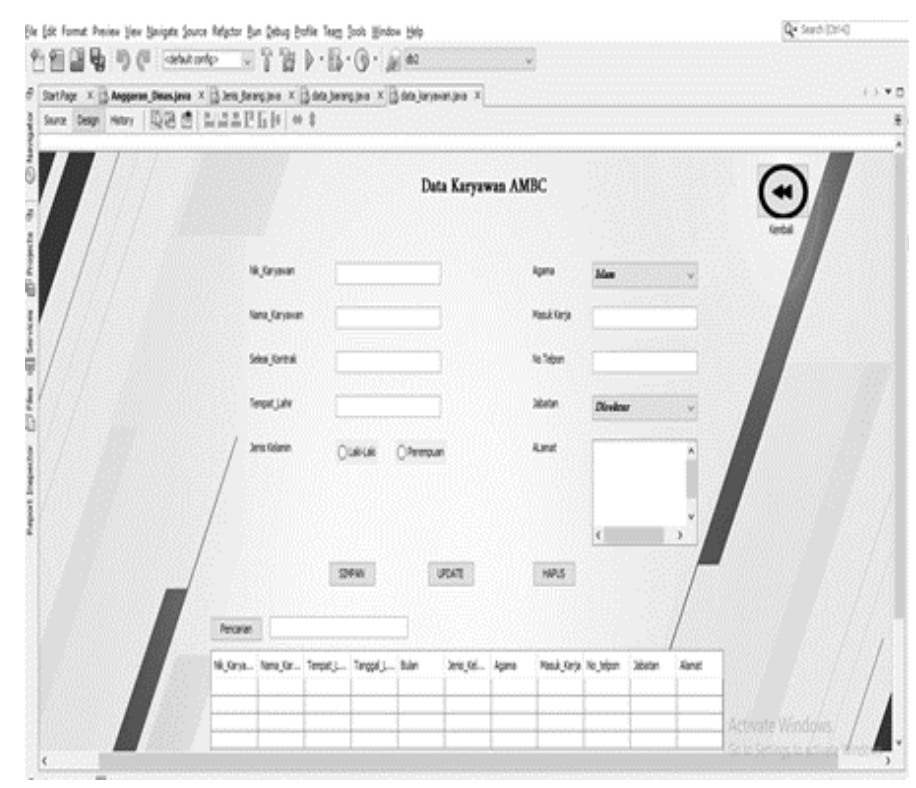

Gambar 4. Tampilan Form Masukan Data karyawan

Menunjukan tampilan menu data karyawan dari menu input data karyawan, menerangkan penginputan data karyawan dengan memasukan data berupa NIK, Nama Karyawan, Jenis Kelamin serta Alamat, dll.

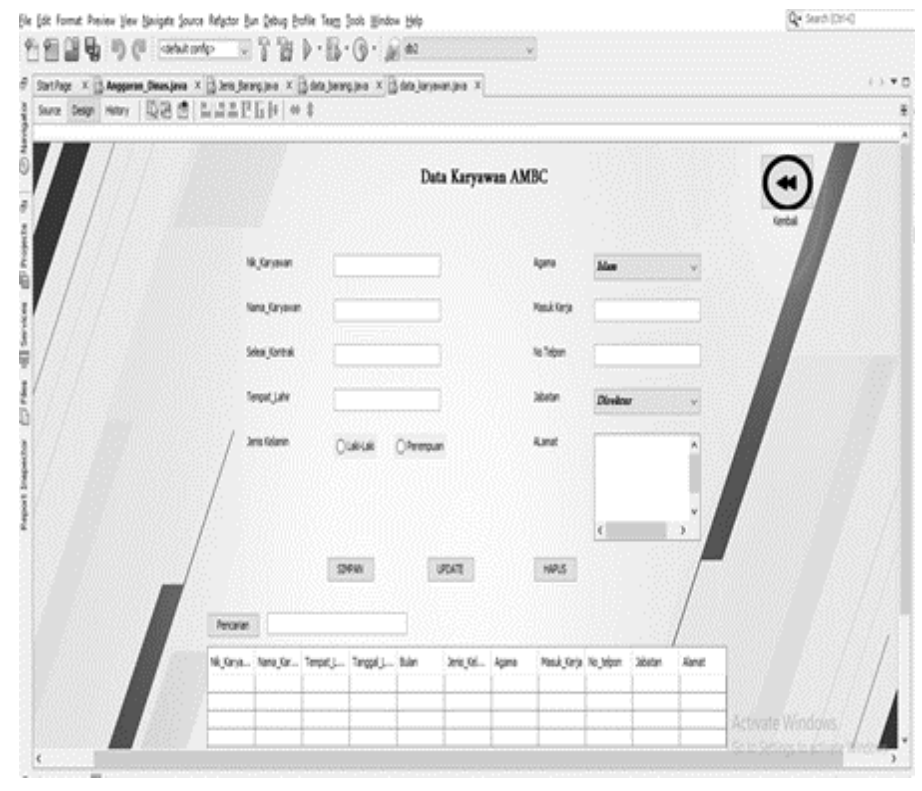




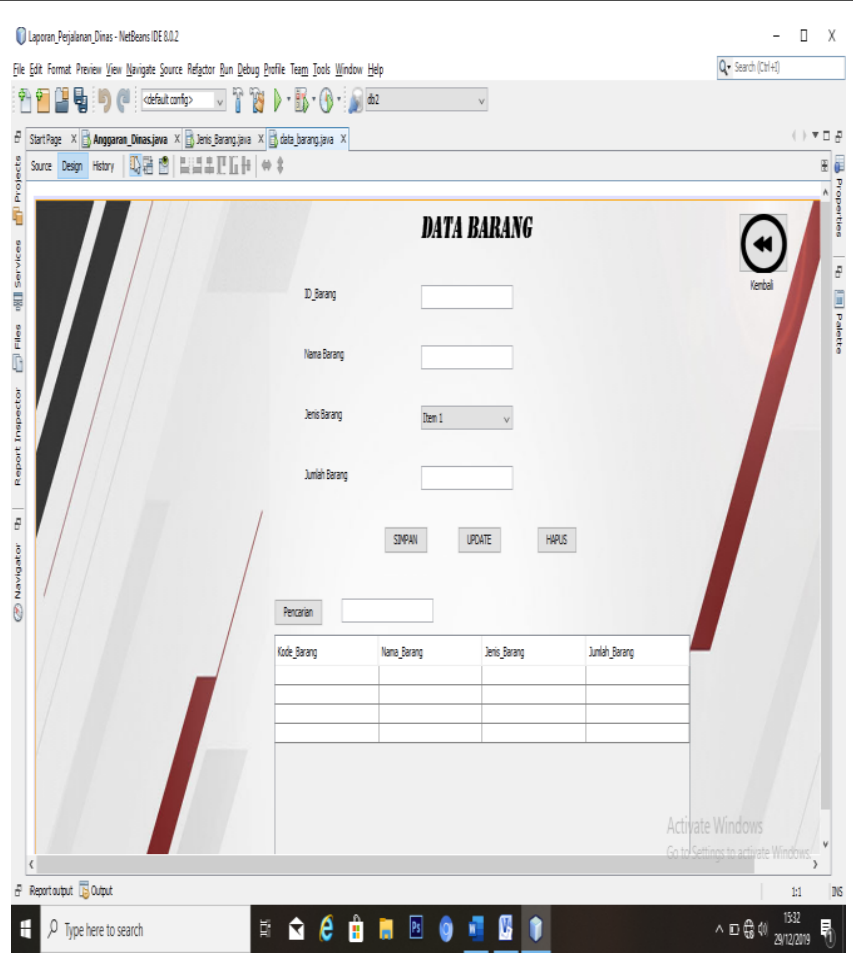

Gambar 5. Tampilan Tampilan Form Masukan Data Barang

Menunjukan tampilan menu data barang dari menu input data, menerangkan penginputan data barang dengan memasukan data berupa Id Barang, Nama Barang, Jenis Barang serta Jumlah Barang.

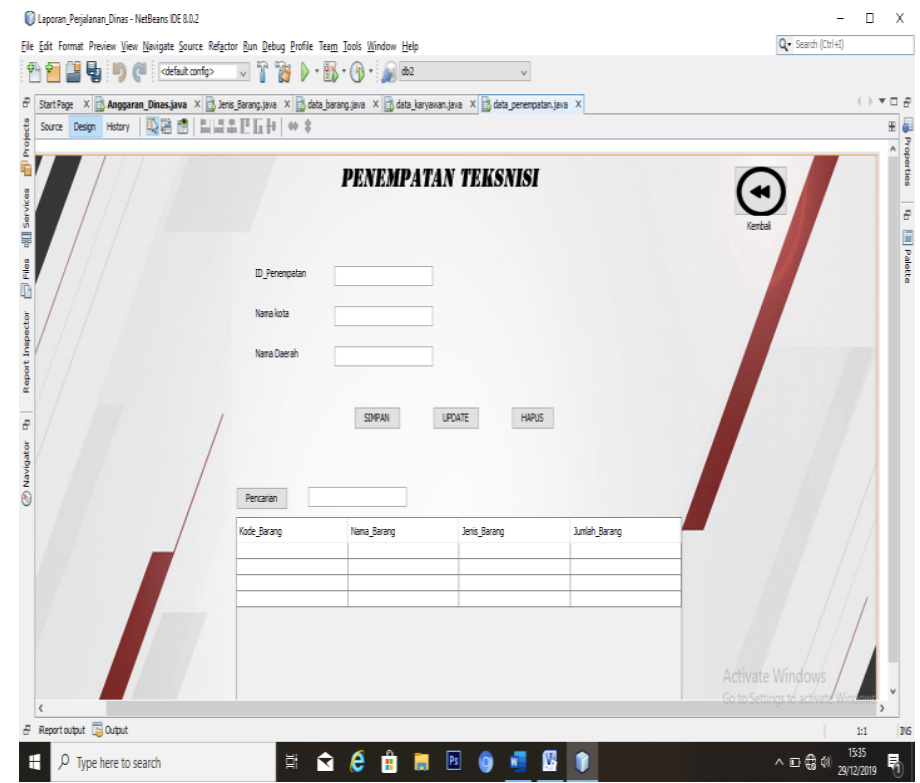

Gambar 6. Tampilan Form Masukan Data Penempatan

Menunjukan tampilan menu data penempatan dari menu input data, menerangkan penginputan data penempatan teknisi dengan memasukan data berupa Id Penempatan, Nama Kota dan Nama Daerah. 


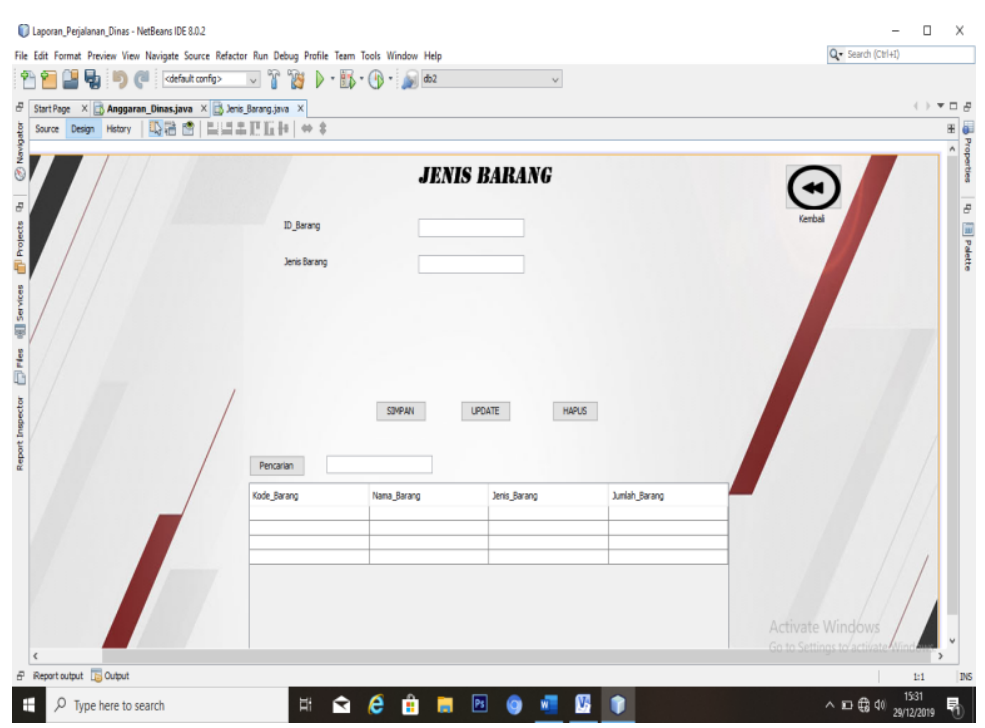

Gambar 7. Tampilan Form Masukan Data Jenis Barang

Menunjukan tampilan menu data jenis barang dari menu input data, menerangkan penginputan data barang dengan memasukan data berupa Id Barang, Nama Barang, Jenis Barang serta Jumlah Barang.

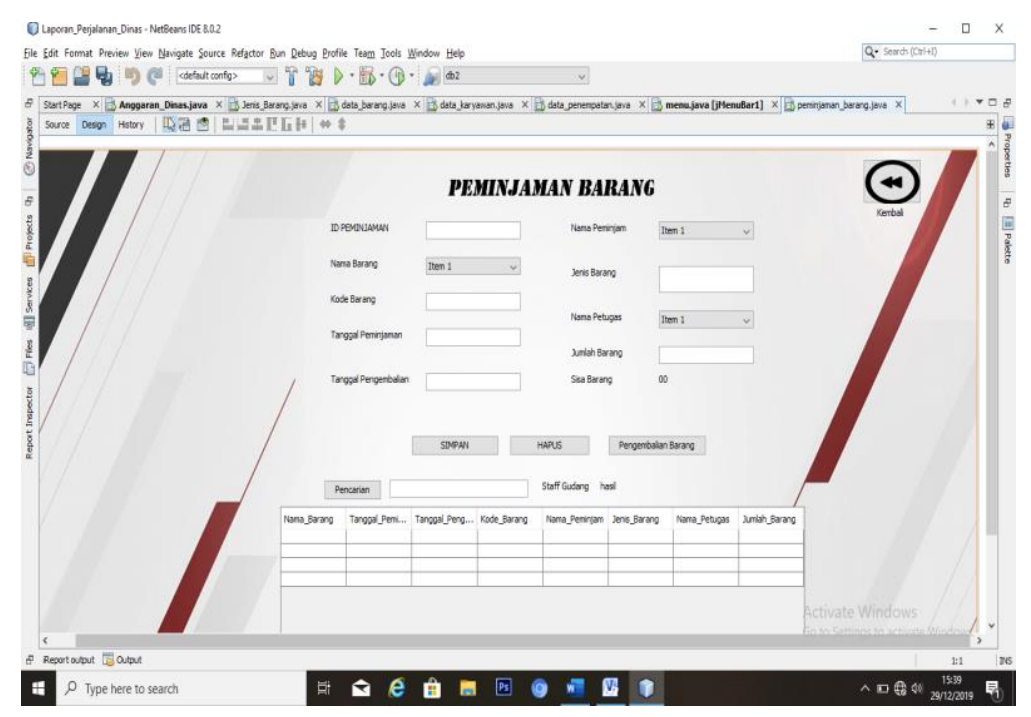

Gambar 8. Tampilan Form Masukan Transaksi Peminjaman Barang 


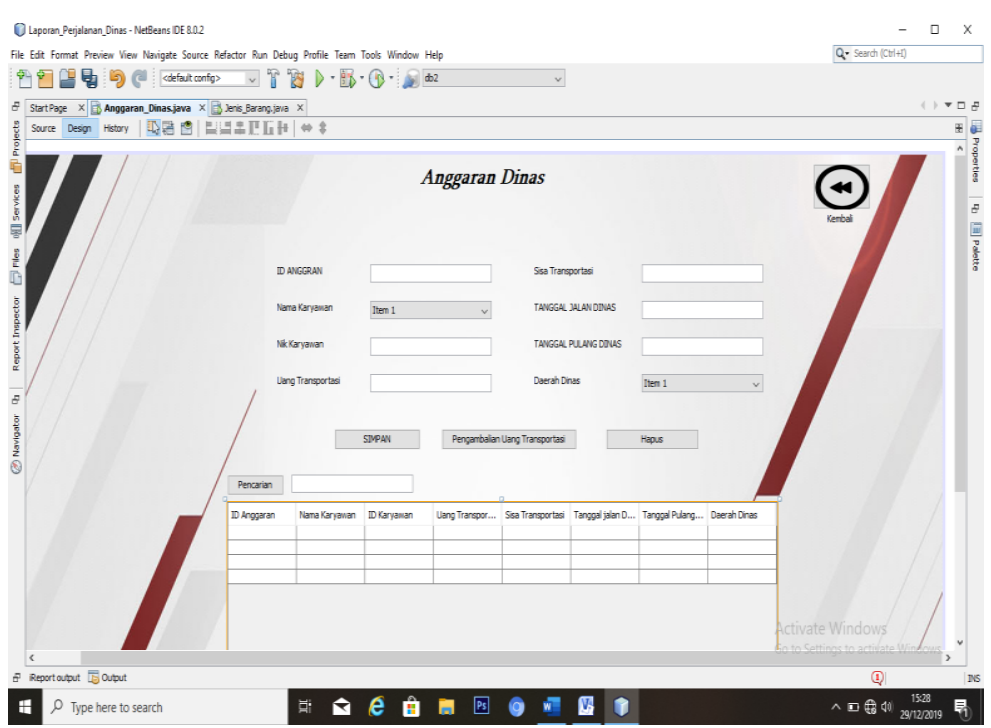

Gambar 9. Tampilan Form Masukan Transaksi Anggaran Dinas

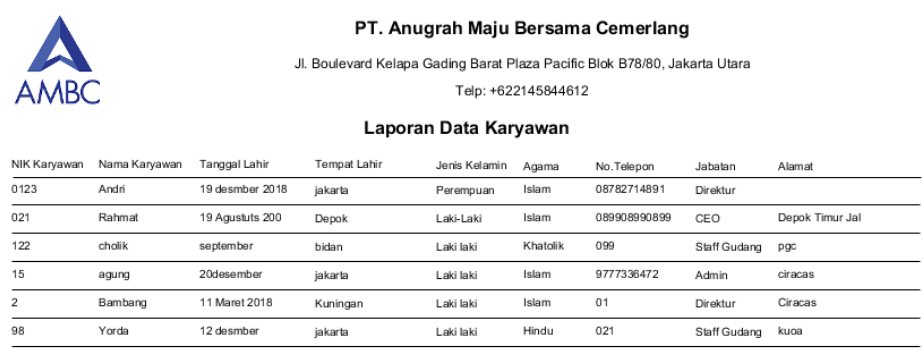

Gambar 10. Tampilan Keluaran Laporan Data Karyawan

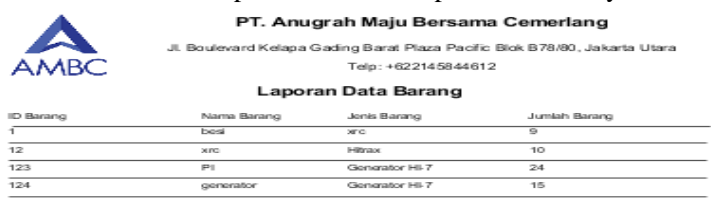

Gambar 11. Tampilan Keluran Laporan Data Barang 


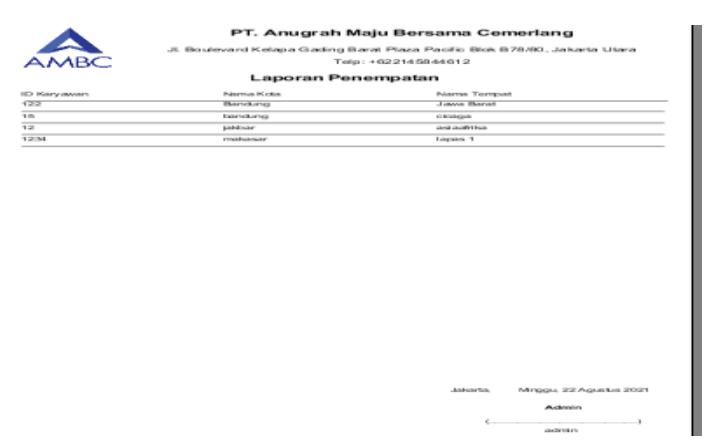

Gambar 12. Tampilan Keluaran Laporan Data Penempatan

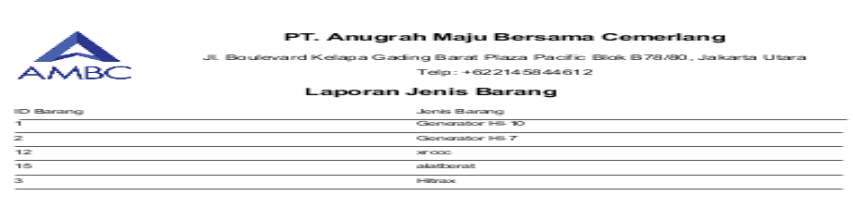

Gambar 13. Tampilan Keluaran Laporan Data Jenis Barang

\section{Kesimpulan}

Berdasarkan analisa yang dilakukan, maka perancangan aplikasi system manajemen anggaran perjalanan dinas luar kota pada PT. AMBC dapat diterapkan dan menjadi salah satu solusi yang tepat bagi perusahaan ini. Sehingga dapat diambil simpulan :

1. Penggunaan aplikasi komputerisasi dapat membantu perusahaan ini dalam mempercepat proses-proses pengolahan data penempatan teknisi sehingga kekurangan pada sistem manual dapat teratasi.

2. Memudahkan pelayanan khususnya di bagian keuangan anggaran dinas luar kota dan peningkatan efisiensi dari berbagai kegiatan.

3. Dapat mengurangi kesalahan-kesalahan yang sering dilakukan oleh kesalahan manusia.

4. Dapat memberikan informasi yang lebih tepat, cepat dan akurat dibandingkan dengan sistem manual yang diberlakukan di perusahaan ini.

5. Aplikasi manajemen anggaran perjalanan dinas luar kota ini membuat input data karyawan serta proses penempatan teknisi yang dilakukan oleh manager lebih cepat serta data tersimpan dengan aman.

\section{Daftar Pustaka}

[1]. Buana, I Komang Setia. (2014). Jago pemrograman PHP. Dunia Komputer: Jakarta, Indonesia.

[2]. Huda, Miftakhul. (2011). Membuat Aplikasi Database dengan Java, MySQL dan NetBeans. Penerbit Jakarta: PT Gramedia.

[3]. Janner Simarmata dan Iman Paryudi. (2012). Basis Data, Andi Offset: Yogyakarta.

[4]. Jogiyanto H.M. (2014). Analisa dan Desain.Penerbit Yogyakarta: C.V Andi Offset. 
[5]. Jogiyanto, Hartono.(2014). Pengenalan Komputer. Penerbit Yogyakarta : Andi Offset.

[6]. Kendall, Kenneth E, Julie E.Kendall, (2012). Analisa dan Perancangan Sistem Jilid 1. Penerbit Jakarta : PT Indeks Kelompok Gramedia.

[7]. Kristanto. (2013). Perancangan Sistem Informasi dan Aplikasinya.Yogyakarta : Graha Ilmu.

[8]. Kurniawan, Hendra, Eri Mardiani, Nur Rahmansyah. (2011). Aplikasi menggunakan Java NetBeans, XAMPPP, dan iReport. PT Elex Media Komputindo. Jakarta.

[9]. Laudon, Kenneth C. dan Laudon, Jane P. (2013). Sistem Informasi Manajemen. Penerbit Yogyakarta : Andi Offset.

[10]. Marlinda, Linda. (2012). Sistem Basis Data. Penerbit Yogyakarta : Andi.

[11]. Siallagan, Sariadin. (2014). Pemrograman Java Dasar- dasar Pengenalan dan Pemahaman. Penerbit Yogyakarta : C.V Andi Offset.

[12]. Sutabri, Tata. (2014). Analisa Sistem Informasi. Penerbit Yogyakarta : Andi.

[13]. Kusrini, M.Kom. (2012). Strategi Perancangan dan Pengolahan Basis Data. Yogyakarta: Andi.

[14]. Marzuki. (2013). Metodologi Riset Panduan Penelitian Bidang Bisnis dan Sosial. Yogyakarta: Ekosiana.

[15]. Mulyadi. (2014). Sistem Akuntansi. Jakarta: Salemba Empat.

[16]. Mulyanto, Agus. (2012). Sistem Informasi Konsep \& Aplikasi. Yogyakarta: Pustaka Pelajar.

[17]. Raharjo, Budi. (2011). Belajar Otodidak Membuat Database menggunakan MySQL. Bandung: Informatika.

[18]. Sutarman. (2012). Pengantar Teknologi Informasi. Yogyakarta : Bumi Aksara.

[19]. Wahyono, Teguh. (2013). Sistem Informasi Konsep Dasar, Analisis Desain dan Implementasi. Yogyakarta: Graha Ilmu 